of allergy and a personal history of hay fever in the asthmatic group than the non-wheezers.

Not only was the prevalence of asthma higher in men than women but the disease also seemed to be more severe. Only four men were classed as having mild asthma or being ex-asthmatic but their lung function was noticeably impaired whereas the lung function of the 11 women in the same class resembled that of the non-wheezy women. The other wheezers included more smokers than the other groups and many of them seemed to have some degree of chronic bronchitis. Focal eosinophils and other asthmatic stigmata were associated with both a clinical diagnosis of asthma and individual characteristics of the disease. Many subjects, however, produced an asthmatic type of sputum without having any symptoms, as noted by Brown. ${ }^{10}$ Presumably such people have asthmatic tendencies without actually developing the overt disease. On the other hand some patients seemed to have clinical asthma but either they could not produce a specimen or their sputum showed no eosinophilia. If more specimens had been obtained from each subject some might have proved positive, since eosinophilia may be present intermittently. Perhaps two underlying disease processes exist that fulfil our criteria for asthma in the elderly, one causing sputum eosinophilia and the other a form of chronic bronchitis with reversible airways obstruction. This possibility is supported by the four current asthmatics who were clinically diagnosed as having chronic bronchitis plus asthma but showed no blood or sputum eosinophilia or positive skin tests.
We thank the general practitioners of Barry for their help and interest, and Dr T E Parry for the blood eosinophil counts.

Requests for reprints should be addressed to Dr M L Burr, MRC Epidemiology Unit, 4 Richmond Road, Cardiff.

\section{References}

${ }^{1}$ Sanerkin, N G, and Evans, D M D, fournal of Pathology and Bacteriology, 1965, 89, 535 .

${ }^{2}$ Burr, M L, et al, Thorax, 1975, 30, 663.

${ }^{3}$ Lee, H Y, and Stretton, T B, British Medical fournal, 1972, 4, 93.

4 Ford, R M, Medical fournal of Australia, 1969, 1, 628.

${ }^{5}$ MRC Committee on Aetiology of Chronic Bronchitis, Lancet, 1965, 1, 775.

${ }^{6}$ Manners, B T B, Journal of the Royal College of General Practitioners, 1974, 24, 167.

' Gough, J, Acta Allergologica, 1961, 16, 391.

${ }^{8}$ Epstein, R L, Annals of Internal Medicine, 1972, 77, 259

${ }^{9}$ Stretton, T B, and Lee, H Y, British Medical fournal, 1973, 1, 110

${ }^{10}$ Brown, H M, Lancet, 1958, 1, 1245.

${ }^{11}$ Broder, L, Barlow, P P, and Horton, R J M, fournal of Allergy, 1962, 33, 513.

12 Arbeiter, H E, Clinical Pediatrics, 1967, 6, 140

${ }_{13}$ Dawson, B, et al, Lancet, 1969, 1, 827.

${ }^{14}$ Williams, H, and McNicol, K N, British Medical fournal, 1969, 4, 321.

${ }^{15}$ Burr, M L, Eldridge, B A, and Borysiewicz, L K, Archives of Disease in Childhood, 1974, 49, 923.

${ }^{16}$ Hamman, R F, Halil, T, and Holland, W W, British fournal of Preventive and Social Medicine, 1975, 29, 228.

17 Smith, J M, British fournal of Diseases of the Chest, 1976, 70, 73.

(Accepted 2 March 1979)

\title{
Comparison of black and white patients attending hypertension clinics in England
}

\author{
A D MUNRO-FAURE, L J BEILIN, C J BULPITT, E C COLES, C T DOLLERY, J S S GEAR, \\ GILLIAN HARPER, B F JOHNSON
}

British Medical fournal, 1979, 1, 1044-1047

\section{Summary and conclusions}

Reports suggest that hypertension and death due to hypertensive disease are commoner among black than among white people. One hundred and thirty-five black patients attending hypertension clinics at three English

Department of the Regius Professor of Medicine, Oxford

L J BEILIN, MD, FRCP, clinical reader (now professor of medicine, University of Western Australia, Perth)

J S S GEAR, MB, DPH, fellow

Department of Clinical Pharmacology, Royal Postgraduate Medical School, London

C J BULPITT, MD, MRCP, honorary consultant physician

C T DOLLERY, MB, FRCP, professor

Department of Renal Medicine, King's College Hospital, London

B F JOHNSON, MB, MRCP, honorary clinical assistant (now professor of medicine and pharmacology, University of Massachussetts, Worcester, Massachussetts)

A D MUNRO-FAURE, BM, FRCP, honorary consultant physician (present address: Dulwich Hospital, London SE22 8PT)

Division of Computing and Statistics, Clinical Research Centre, Harrow, London

E C COLES, $M B, M T E C H$, member of scientific staff

GILLIAN HARPER, programmer hospitals were compared with age-, sex-, and clinicmatched white patients. The black women had higher blood pressures and weighed more than the white women, but there were no differences between the men.

The black patients had no increased risk from family, obstetric, or smoking history. Proteinuria and nocturia were more common in black patients while urinary infections were less common. Heart size and left ventricular voltage were greater in black patients. Haemoglobin and plasma cholesterol and triglyceride concentrations were smaller and serum globulin concentration greater in black patients.

No difference in response to treatment, attributable to race, was observed during the period of clinic attendance, which averaged 1.7 years. There was a slightly greater rate of default among black men during the first year of attendance.

\section{Introduction}

Surveys in the United States ${ }^{1-5}$ and Caribbean ${ }^{6-8}$ have consistently shown higher blood pressures in black than in white people. Death rates from hypertensive heart disease and cerebrovascular disease in the United States ${ }^{9}$ and in the United Kingdom $^{10}$ show similar differences. Since 1971 information about patients attending hypertension clinics at Hammersmith Hospital, the Radcliffe Infirmary, and King's College Hospital has been stored in a computer-based file. ${ }^{11}$ This file was examined to establish whether there were differences in clinical features at 
presentation between black and white patients, whether treatment was equally effective in controlling blood pressure, and whether patient management differed between the two groups.

\section{Patients and methods}

The records of the first 1743 patients were searched to identify those with untreated blood pressures greater than $145 / 95 \mathrm{~mm} \mathrm{Hg}$ within a year before or six months after first attending. Altogether 968 white and 142 black patients were identified. Nineteen of the latter were born in Africa, one in the United Kingdom, and the remainder in the Caribbean. The percentage of black patients attending each clinic differed, and more of the black patients were women. The mean age of black men was $42 \cdot 9 \pm 9 \cdot 3$ (SD), of white men $50 \cdot 0 \pm 12 \cdot 4$, of black women $42 \cdot 2 \pm 10 \cdot 0$, and of white women $49 \cdot 9 \pm 14 \cdot 2$ years. Because of these differences a clinic-, sex-, and age-matched control was selected for each patient. This was successful in 135 instances and the analyses reported were performed on these matched pairs. In some cases data was not available for all 135 pairs.

The frequency of certain symptoms, historical features, and physical signs at first attendance were compared (by $\chi^{2}$ test), as were means for measured continuous variables for each race and sex separately (by Student's $t$ test). For measurements from chest or kidney radiographs or ECGs further matched white controls were selected, when necessary, to ensure that numbers approximated those of the black patients tested.

Mean systolic and diastolic pressure was computed for each patient for each six-month period of follow-up. Group means were then computed for each six-month period for each race separately. The numbers of patients of each race who died, defaulted, or were discharged in each year of follow-up were studied. Patients were categorised as defaulters if they did not return within six months after the original appointment which they failed to keep. Deaths were reported by the Office of Population Censuses and Surveys.

\section{Results}

Mean ages, heights, weights, and untreated systolic and diastolic blood pressures are listed in table I. Black women were significantly heavier than white women and had slightly but significantly greater mean diastolic pressure. Mean systolic pressure was not significantly different. The average blood pressures of black and white women weighing less than $70 \mathrm{~kg}$ and white women weighing more than $70 \mathrm{~kg}$ did not differ significantly and were respectively $168 \pm 26 / 107 \pm 13 \mathrm{~mm}$ $\mathrm{Hg}(\mathrm{n}=42), 172 \pm 31 / 106 \pm 12 \mathrm{~mm} \mathrm{Hg}(\mathrm{n}=58)$, and $173 \pm 32 / 109 \pm 19$ $\mathrm{mm} \mathrm{Hg}(\mathrm{n}=27)$. The average blood pressure of black women weighing more than $70 \mathrm{~kg}$ was $184 \pm 31 / 117 \pm 17(\mathrm{n}=42)$ and differed significantly from that of those weighing less than $70 \mathrm{~kg}$. There were no significant differences between black and white men.

When patients first attended, $71 \%$ of their fathers and $47 \%$ of their mothers had died. Mean age at death of fathers was 62 and of mothers 63 years. There were no differences attributable to the patients' sex or race.

More black than white women had been pregnant $(P<0.05$; table II). Among those with adequate records, however, more white than black women gave a history of hypertension in pregnancy, though the difference was not significant.

Twenty-seven out of 58 black and 29 out of 60 white men were non-smokers, but more black (61/77) than white women (48/84) were non-smokers. Median daily cigarette consumption in white patients

TABLE I-Mean $( \pm S D)$ age, height, weight, and untreated systolic and diastolic blood pressure for sexes and races separately. Numbers of patients are given in parentheses

\begin{tabular}{|c|c|c|c|c|c|}
\hline \multirow[b]{2}{*}{ 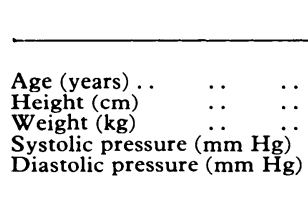 } & \multicolumn{3}{|c|}{ Black } & \multicolumn{2}{|l|}{ White } \\
\hline & $\begin{array}{l}\cdots \\
\cdots \\
\cdots \\
\cdots\end{array}$ & $\begin{array}{c}44 \cdot 2 \pm 9 \cdot 6 \\
172 \cdot 9 \pm 7 \cdot 2 \\
79 \cdot 0 \pm 13 \cdot 2 \\
174 \cdot 8 \pm 23 \cdot 61 \\
115 \cdot 0 \pm 14 \cdot 16\end{array}$ & $\begin{array}{l}(50) \\
(50) \\
(50) \\
(46) \\
(46)\end{array}$ & $\begin{array}{c}n 4 \cdot 0 \pm 9 \cdot 9 \\
171.5 \pm 8 \cdot 7 \\
80 \cdot 9 \pm 15 \cdot 6 \\
173 \cdot 5 \pm 23 \cdot 46 \\
111.9 \pm 14.90\end{array}$ & $\begin{array}{l}(50) \\
(50) \\
(50) \\
(49) \\
(49)\end{array}$ \\
\hline 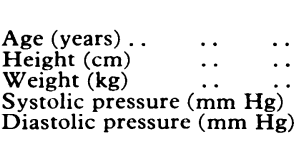 & $\begin{array}{l}\cdots \\
\cdots \\
\cdots\end{array}$ & $\begin{array}{c}42 \cdot 6 \pm 10 \cdot 0 \\
160 \cdot 7 \pm 6 \cdot 8 \\
71 \cdot 1 \pm 14 \cdot 3^{*} \\
180 \cdot 1 \pm 28 \cdot 0 \\
112 \cdot 0 \pm 15 \cdot 62^{*}\end{array}$ & $\begin{array}{l}4 \\
(85) \\
(72) \\
(85) \\
(79) \\
(79)\end{array}$ & $\begin{array}{c}42 \cdot 8 \pm 9 \cdot 9 \\
158 \cdot 9 \pm 5 \cdot 1 \\
66 \cdot 1 \pm 14 \cdot \cdot^{*} \\
174 \cdot 0 \pm 26 \cdot 3 \\
107 \cdot 4 \pm 12 \cdot 64^{*}\end{array}$ & $\begin{array}{l}(85) \\
(72) \\
(85) \\
(77) \\
(77)\end{array}$ \\
\hline
\end{tabular}

$* \mathrm{P}<0.05$.
TABLE II-Number of women giving a history of pregnancy and of raised blood pressure during pregnancy

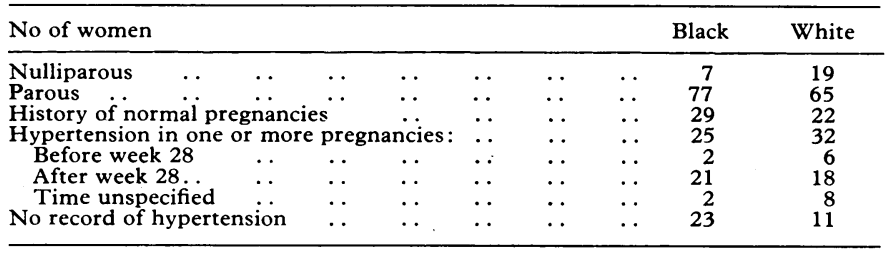

(15/day, both sexes) was greater than in black patients (10/day in men, $8 /$ day in women).

There were no significant differences in the frequencies with which the following symptoms or illnesses were reported by the two groups at the first visit, and the percentage incidence for the groups combined was: angina pectoris $3.9 \%$, intermittent claudication $0 \%$, myocardial infarction $0.5 \%$, breathlessness on exertion $16.7 \%$, ankle swelling $1.7 \%$, a history of heart failure $0.9 \%$, transient paresis $1.2 \%$, transient loss of vision $2.3 \%$, transient loss of consciousness $4.9 \%$, stroke $2.0 \%$, haematuria $1.6 \%$, dysuria $1.6 \%$.

A history of migraine was given by 17 out of 122 white and by seven out of 127 black patients for whom there were records. Although this difference was statistically significant $(P<0.05)$, black patients reported headaches more often $(86 / 134)$ than white patients $(72 / 131)$. Fewer blacks gave a history of depressive illness requiring treatment: 23 out of 82 white women $(28 \%), 15$ out of 79 black women $(19 \%)$, seven out of 45 white men $(16 \%)$, and only four out of 45 black men $(9 \%)$; the racial differences were not statistically significant.

Nocturia was reported by 27 out of 84 blacks and by 10 out of 103 white patients $(P<0.001)$, and proteinuria was found in 33 out of 120 black compared with 21 out of 129 white patients $(P<0.05)$. There were no differences attributable to sex. Although not quite statistically significant $(P=0.06)$, however, evidence of a urine infection was found in 10 out of 66 white women but in only two out of 53 black women whose urines were cultured within a year of their first visit. No men with urine infections were found.

Papilloedema was noted in one and retinal haemorrhages in five black patients; only one white patient had severe retinopathy.

Table III shows the cardiothoracic ratios calculated from chest radiographs in 92 black and 92 white patients. Although unfolding of

TABLE III-Measurements on chest radiographs and cardiothoracic ratios in black and white patients

\begin{tabular}{|c|c|c|c|}
\hline & Black patients & White patients & $\mathbf{P}$ \\
\hline $\begin{array}{l}\text { No with enlarged heart } \\
\text { Mean cardiac diameter }(\mathrm{cm}) \ldots \\
\text { Mean thoracic diameter }(\mathrm{cm}) \ldots \\
\text { Cardiothoracic ratio } \ldots\end{array}$ & \begin{tabular}{lll}
\multicolumn{1}{c}{$45 / 92$} \\
$\ldots$ & $14.4 \quad \pm 1.55$ \\
$\therefore$ & 27.5 & \pm 2.42 \\
. & 0.510 & \pm 0.06
\end{tabular} & $\begin{array}{l}18 / 92 \\
13 \cdot 3^{18 / 9} \pm 1 \cdot 71 \\
28 \cdot 3 \pm 2 \cdot 5 \\
0 \cdot 466 \pm 0.05\end{array}$ & $\begin{array}{l}<0.001 \\
<0.001 \\
<0.001 \\
<0.001\end{array}$ \\
\hline
\end{tabular}

the aorta was reported more often in black (22/87) than in white patients (13/73), the difference was not significant. In 74 ECG records from black and 73 from matched white patients the mean sum of SV1 and RV5-6 was $32.6( \pm 10.32) \mathrm{mm}$ in the black and $25.9( \pm 8.48)$ $\mathrm{mm}$ in the white patients $(\mathbf{P}<0.001)$. Similarly, this sum exceeded $35 \mathrm{~mm}$ in $40 \%$ of records from black compared with $18 \%$ of records from white patients $(P<0.01)$

Mean kidney lengths measured from radiographs were similar for matched groups of 29 patients. Radiological evidence of pyelonephritis was seen in five patients from each group.

Significant racial differences were found in haemoglobin and in mean plasma concentrations of total protein, globulin, cholesterol and fasting triglycerides (table IV). No differences were found for plasma concentrations of sodium, potassium, bicarbonate, chloride, urea, creatinine, uric acid, calcium, inorganic phosphate, albumin, or glucose or for 24-hour urinary excretion of 3-methoxy 4-hydroxymandelic acid.

Group mean systolic and diastolic blood pressures for each sixmonth period of follow-up are compared in the figure. After the first two years there was little further fall in blood pressures. The numbers of black and white patients attending the combined clinics during the five years after entry (average 1.7 years) are shown in table $\mathrm{V}$, with the numbers dying, discharged, or defaulting during the same periods. Six white and four black patients died during follow-up. Discharge 
TABLE IV-Mean $( \pm S D)$ concentrations of haemoglobin and plasma total protein, globulin, cholesterol and fasting triglycerides in black and white patients

\begin{tabular}{|c|c|c|c|c|c|c|c|}
\hline & \multicolumn{3}{|c|}{ Black } & \multicolumn{3}{|c|}{ White } & \multirow[b]{2}{*}{$\mathbf{P}$} \\
\hline & \multicolumn{2}{|r|}{ Mean } & $\begin{array}{c}\text { No of } \\
\text { patients }\end{array}$ & \multicolumn{2}{|r|}{ Mean } & $\begin{array}{c}\text { No of } \\
\text { patients }\end{array}$ & \\
\hline $\begin{array}{l}\text { Haemoglobin (g/dl) } \\
\text { Total protein }(\mathrm{g} / \mathrm{l}) \\
\text { Globulin }(\mathrm{g} / \mathrm{l}) \\
\text { Cholesterol (mmol } / \mathrm{l}) \\
\text { Fasting triglycerides }\end{array}$ & $\begin{array}{lr}\ldots 13.2 \\
\ldots 75.4 \\
\ldots 32.4 \\
\ldots & 5.9 \\
\ldots & \end{array}$ & $\begin{array}{l} \pm 1.67 \\
\pm 5.04 \\
\pm 4.97 \\
\pm 1.21\end{array}$ & $\begin{array}{r}105 \\
110 \\
110 \\
98\end{array}$ & $\begin{array}{r}14 \cdot 2 \\
72 \cdot 9 \\
29 \cdot 3 \\
6 \cdot 3\end{array}$ & $\begin{array}{l} \pm 1 \cdot 29 \\
\pm 5.51 \\
\pm 4 \cdot 36 \\
\pm 1.33\end{array}$ & $\begin{array}{r}90 \\
101 \\
101 \\
101\end{array}$ & $\begin{array}{l}<0.001 \\
<0.001 \\
<0.001 \\
<0.05\end{array}$ \\
\hline$\underset{(\mathrm{mmol} / \mathrm{l})}{\text { Fasting triglycerides }}$ & 0.85 & $58 \pm 0.352$ & 19 & 1.23 & $38 \pm 0.678$ & 32 & $<0.05$ \\
\hline
\end{tabular}

Conversion: SI to traditional units-Cholesterol: $1 \mathrm{mmol} / 1 \approx 38.6 \mathrm{mg} / 100 \mathrm{ml}$ Triglycerides: $1 \mathrm{mmol} / 1 \approx 88.5 \mathrm{mg} / 100 \mathrm{ml}$.

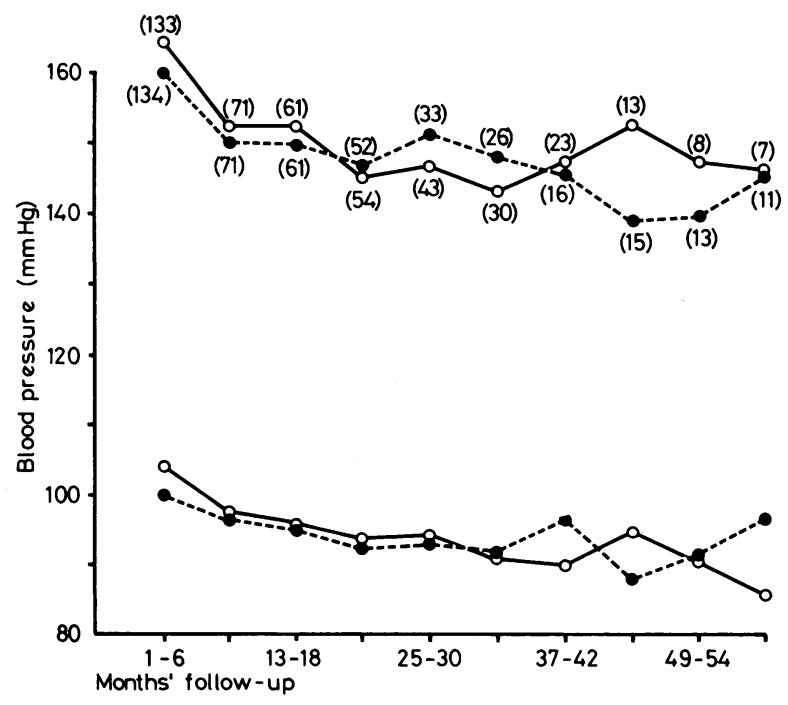

Group mean systolic and diastolic blood pressures of black $(\mathrm{O}-\mathrm{O})$ and white -.- 0 patients at varying periods after first attendance. Numbers of patients contributing to each mean are given in parentheses.

TABLE v-Numbers of white and black patients followed for varying periods at the combined clinics with numbers dying, discharged, or defaulting each year

\begin{tabular}{|c|c|c|c|c|c|c|c|}
\hline \multicolumn{3}{|c|}{ Duration of follow-up (years): $0-1$} & $1-2$ & $2-3$ & $3-4$ & $4-5$ & $>5$ \\
\hline $\begin{array}{l}\text { No at risk ... } \\
\text { No dying } .0 \\
\text { No discharged } \\
\text { No defaulting }\end{array}$ & $\begin{array}{l}\cdots \\
\cdots \\
\cdots\end{array}$ & $\begin{array}{lr}\ldots & 135 \\
\therefore & 1 \\
\therefore & 30 \\
. & 20\end{array}$ & $\begin{array}{r}76 \\
0 \\
8 \\
8\end{array}$ & $\begin{array}{r}41 \\
1 \\
2 \\
4\end{array}$ & $\begin{array}{r}24 \\
2 \\
1\end{array}$ & $\begin{array}{r}15 \\
2 \\
1\end{array}$ & $\begin{array}{l}9 \\
0\end{array}$ \\
\hline $\begin{array}{l}\text { No at risk ... } \\
\text { No dying . } \\
\text { No discharged } \\
\text { No defaulting }\end{array}$ & $\begin{array}{l}\cdots \\
\cdots \\
\cdots\end{array}$ & $\begin{array}{lr}\ldots & 135 \\
\ldots & 1 \\
\ldots & 28 \\
\ldots & 27\end{array}$ & $\begin{array}{r}72 \\
2 \\
3 \\
7\end{array}$ & $\begin{array}{r}44^{E} \\
1 \\
3 \\
3\end{array}$ & $\begin{array}{r}22 \\
0 \\
4 \\
1\end{array}$ & $\begin{array}{l}8 \\
0\end{array}$ & $\begin{array}{l}5 \\
0\end{array}$ \\
\hline
\end{tabular}

rates were similar for both races. There was a slightly greater rate of default for black than for white patients during the first year. This was confined to men (13 black, four white men; 14 black, 16 white women).

\section{Discussion}

Differences of blood pressure between black and white men were insignificant $(1 \cdot 3 / 3.1 \mathrm{~mm} \mathrm{Hg})$, and indicate that referral criteria were similar. Because patients attending a clinic are a selected population, referred mainly because their blood pressure is increased, we cannot conclude that the average blood pressure of black and white people in the community is similar, for United States population surveys have shown rather larger racial differences $(9 \cdot 7 / 7.0 \mathrm{~mm} \mathrm{Hg}$ at ages 35 to 44 , and 7.9 / $7.6 \mathrm{~mm} \mathrm{Hg}$ at 45 to 54 in men; $7.9 / 7.6 \mathrm{~mm} \mathrm{Hg}$ at 35 to 44 , and $19.7 / 10.5 \mathrm{~mm} \mathrm{Hg}$ at 45 to 54 in women). ${ }^{5}$

Differences of blood pressure between black and white women that we found $(6 \cdot 1 / 4.6 \mathrm{~mm} \mathrm{Hg})$ may be related to the greater weight of the black women. Saunders and Bancroft ${ }^{6}$ from the Virgin Islands and Boyle et $\mathrm{al}^{4}$ from South Carolina found little or no relationship between weight and blood pressure in black women, but Miall et al ${ }^{12}$ from Jamaica and Florey et $a l^{13}$ from Guyana noted positive relationships. There was no evidence that the higher blood pressure of black women was associated with obstetric history. On the contrary, nulliparity and a history of hypertension in pregnancy, both associated with high blood pressure, were less common in black than in white women.

If genetic factors are importantly related to blood pressure and if hypertension reduces life expectancy, age at death of parents may represent a useful, if seldom quoted, statistic. In this small series there was no difference in the reported age at death of parents of black and white patients.

Urinary infections in black women $(4 \%)$ were less common than in white women $(15 \%)$ or the black hypertensive Jamaican women $(15 \%)$ studied by Miall et al. ${ }^{12}$ But proteinuria was more common in black than in white patients, confirming the results of American ${ }^{1-3}$ and Caribbean ${ }^{14}$ studies. This racial difference in protein excretion is unexplained and does not seem to be related to a greater incidence of radiological abnormality or to a greater impairment of renal function in black patients. Nocturia was also reported much more often by black (32\%) than by white patients $(10 \%)$. Schneckloth et al ${ }^{14}$ commented that in St Kitts "nocturia seemed to be a domestic ritual among both sexes at all ages," but no reports have shown that the high incidence of nocturia in black subjects is attributable to social rather than to physiological factors.

The observation that a history of migraine is more commonly given by white than by black patients may be attributable to a true difference, but might be semantic. The prevalence in white patients is similar to that reported in British population surveys. ${ }^{15}$

Ashcroft and Miall, ${ }^{16}$ comparing radiograph measurements made in Wales and Jamaica, attributed the greater cardiothoracic ratio of black patients to a smaller thoracic rather than a larger cardiac diameter. Our findings show that although the thoracic diameter is smaller in black than white patients (average different $0.8 \mathrm{~cm}$ ) the difference of cardiac diameter is greater (average difference $1 \cdot 1 \mathrm{~cm}$ ). Many studies ${ }^{17}$ have described the greater amplitude of QRS complexes in precordial ECG leads from healthy black than from white subjects. We confirmed the high incidence in black hypertensive patients of changes usually attributed to left ventricular hypertrophy. ${ }^{1819}$ The observed difference between the groups in haemoglobin ${ }^{20}$ and plasma globulin, ${ }^{21}$ cholesterol, and triglyceride ${ }^{22}$ concentrations also confirm previous reports.

It has been suggested ${ }^{2324}$ that black patients may respond less well to treatment than others. The number of patients followed for appreciable periods in this study was too small to allow us to draw any conclusions, but no evidence of a major difference in response is apparent from the blood pressures plotted in the figure. Similarly, except for the tendency of black men to default more often during the first year of treatment, which increases the difficulty of assessing possibly differing responses to treatment, racial differences appeared not to affect management.

We are grateful to the Nuffield Provincial Hospitals Trust and the Department of Health and Social Security for financial support. We thank former and present members of the programming and medical teams, and our past and present clinic nurses and secretaries for their help.

\section{References}

${ }^{1}$ Adams, J M, American fournal of Medical Science, 1932, 184, 342.

2 Comstock, G W, American fournal of Hygiene, 1957, 65, 271.

${ }^{3}$ McDonough, J R, Garrison, G E, and Hames, C G, The Epidemiology of Hypertension, ed J Stamler, R Stamler, and T R Pullman, p 167. New York, Grune and Stratton, 1967.

${ }^{4}$ Boyle, E, et al, in The Epidemiology of Hypertension, ed J Stamler, $\mathrm{R}$ Stamler, and T R Pulman, p 193. New York, Grune and Stratton, 1967. 
${ }^{5}$ Roberts, J, and Maurer, K, Vital and Health Statistics, Series II, 203. Washington, National Centre for Health Statistics, 1977.

${ }^{6}$ Saunders, G M, and Bancroft, H, American Heart fournal, 1942, 23, 410.

${ }^{7}$ Moser, M, et al, American fournal of Cardiology, 1959, 4, 727.

8 Johnson, B C, and Remington, R D, fournal of Chronic Diseases, 1961, 13, 39.

9 Grove, R D, and Hetzel, A M, Vital Statistics Rates in the United States 1940-1960. Washington, National Centre for Health Statistics, 1969.

10 Adelstein, A M, British Medical fournal, 1978, 2, 983.

${ }^{11}$ Beilin, L J, et al, British Medical fournal, 1974, 2, 212.

12 Miall, W E, et al, British Medical fournal, 1962, 2, 497.

${ }^{13}$ Florey, C du V, Ashcroft, M T, and Miller, G J, American fournal of Epidemiology, 1971, 94, 419.

14 Schneckloth, R E, et al, American Heart fournal, 1962, 63, 607.

15 Waters, W E, Headache, 1970, 9, 4.
${ }^{16}$ Ashcroft, M T, and Miall, W E, American fournal of Epidemiology, 1969, 89, 161 .

17 Ashcroft, M T, et al, American Heart fournal, 1971, 81, 467.

18 Stuart, K L, MacIver, C, and Nicholson, J A, British Medical fournal, $1972,2,21$.

19 Entwisle, G, et al, Circulation, 1977, 55, 792.

${ }^{20}$ Devine, B, Vital and Health Statistics, Series II, No 24. Washington, National Centre for Health Statistics, 1967.

${ }^{21}$ Keltz, H, and Comstock, G W, New England fournal of Medicine, 1959, $260,1268$.

22 Slack, J, et al, British Medical fournal, 1977, 2, 353.

${ }^{23}$ McFate Smith, W, Circulation Research, 1977, 40, Suppl, pp 1-98.

${ }^{24}$ Jennings, K, and Parsons, V, British Fournal of Clinical Pharmacology, 1976, suppl, p 773.

(Accepted 7 March 1979)

\section{Summary and conclusions}

A localised outbreak of trichinosis occurred in January 1976 in the southern suburbs of Paris. A total of 125 cases was recorded including 30 children. The prominent symptoms were oedema of the face or eyelids, fever, and myalgia; diarrhoea was unusual and constipation common. An increased blood eosinophil count and raised serum concentrations of muscular enzymes strongly indicated trichinosis. This diagnosis was confirmed later immunologically. The parasite was found in only three out of 32 muscle biopsy specimens but this investigation was made relatively early in the disease. No deaths occurred. In all cases clinical recovery was fast and serum antibody titres were maximum during the first month and decreased slowly. The disease was milder and the recovery faster in children than adults.

Epidemiological study suggested that horse meat was responsible for the infection, though no meat could be examined.

\section{Introduction}

Trichinosis is now rare, although endemic cases have occurred in Switzerland, ${ }^{1}$ Germany, ${ }^{2}$ central Europe, Asia, Africa, the United States, ${ }^{3}$ and arctic areas. In France, although a few cases have persisted in animals, the disease completely disappeared in man after the last epidemic in 1878 due to improved hygiene and adequate food regulations. Recently some cases, all originating abroad, have occurred. In May 1975, 70 people were infected in

\footnotetext{
Departments of Parasitology and Internal Medicine, Hôpital de Bicêtre, 94270 Kremlin-Bicêtre, France

P BOURÉE, MD, senior registrar in parasitology J B BOUVIER, MD, professor of medicine

J PASSERON, MD, associate professor of medicine

Department of Internal Medicine, Hôpital Antoine Béclère, 92141 Clamart, France

P GALANAUD, $\mathrm{MD}$, associate professor of medicine

J DORMONT, MD, professor of medicine
}

Egypt during a dinner at a resort centre, the correct diagnosis being established a few days after French tourists returned home. ${ }^{45}$ In January 1976 an outbreak occurred in the suburbs of Paris. We studied most of the patients affected, and describe here our findings, including the results of follow-up over 18 months. A preliminary report has already been published. ${ }^{6}$

\section{Patients and methods}

We studied 125 patients-that is, almost all those affected-comprising 95 adults and 30 children from 65 families. The ages of the patients ranged from $2 \frac{1}{2}$ to 86 years. They lived in a well-defined area a few miles south of Paris and were all admitted to the university hospitals of Bicêtre and Antoine Béclère. Clinical and laboratory data were collected following a detailed protocol under the constant supervision of one of us (PB). Muscle biopsy specimens were obtained (in adults only) with a Vim-Silvermann needle or surgically.

\section{Results}

\section{ACUTE PHASE}

Most of the patients (90) were admitted to hospital between 17 January and 5 February 1977, their symptoms at presentation being typical. The commonest symptoms were asthenia ( 83 patients; $66 \%$ ), fever $(81 ; 65 \%)$, headache $(76 ; 61 \%)$, myalgia $(74 ; 59 \%)$, and periorbital oedema $(71 ; 57 \%)$. These were severe in $25(20 \%)$ of the cases. Less common findings were nausea (40 patients; $32 \%$ ), conjunctivitis $(39 ; 31 \%)$, arthralgia $(38 ; 30 \%)$, abdominal pain $(33 ; 26 \%)$, and an enlarged spleen $(10 ; 8 \%)$ or liver $(3 ; 2 \%)$. Diarrhoea, usually a common finding, was not observed in any of our patients, while constipation occurred in $60(48 \%)$. An increased eosinophil count was found in $121(97 \%)$ cases, absolute counts being $0.35 \times 10^{9}-3 \times 10^{9} / 1$ $\left(350-3000 / \mathrm{mm}^{3}\right)$ in $95(75 \%)$ cases and $3 \times 10^{9}-8 \times 10^{9} / 1(3000-$ $\left.8000 / \mathrm{mm}^{3}\right)$ in $26(20 \%)$; four patients had borderline or normal values. In adults the erythrocyte sedimentation rate was increased roughly as in fever; it was increased in only four of the 30 children, however, though fever could be pronounced.

The serum concentrations of muscular enzymes, lactate dehydrogenase, aldolase, and creatine phosphokinase were increased in $116(93 \%)$, $75(60 \%)$, and $58(46 \%)$ patients respectively. In contrast, only four out of 52 electromyograms were modified with myogenic alterations without neurogenic disturbances. Muscle biopsy (32 specimens) showed non-specific myositis in $18(57 \%)$ cases and larvae in only three. Non-specific biological changes included an increased leucocyte count (90 patients; $72 \%$ ), increased serum concentrations of $\alpha_{2}$ - and $\gamma$-globulins, ${ }^{7}$ and a decrease in serum calcium concentration. This 